\title{
Enzyme Regulation in Methylobacterium organophilum
}

\author{
By MARY L. O'CONNOR AND RICHARD S. HANSON \\ Department of Bacteriology, University of Wisconsin, \\ Madison, Wisconsin 53706, U.S.A.
}

(Received 6 April 1977)

\begin{abstract}
Several enzymes have been assayed in Methylobacterium organophilum grown on different substrates. The enzymes which are involved in growth on $C_{1}$ compounds were induced by methanol and not repressed by succinate. When succinate-grown bacteria were resuspended in medium containing methanol, four enzymes unique to growth on $\mathrm{C}_{1}$ compounds (hydroxypyruvate reductase, serine-glyoxylate aminotransferase, methanol dehydrogenase and glycerate kinase) were fully induced by the time growth began. When methanol-grown bacteria were resuspended in medium containing succinate, all four enzyme activities decreased. Several mutants unable to grow on $\mathrm{C}_{1}$ compounds were examined for deficiencies in the enzymes specific for growth on these compounds. Seven of the mutants were pleiotropic, and six were not revertible by chemical mutagens, suggesting the possibility of genetic linkage or the presence of a regulon for the genes involved in $\mathbf{C}_{\mathbf{1}}$ metabolism.
\end{abstract}

\section{INTRODUCTION}

In facultative methanol- and methylamine-utilizing bacteria, enzymes that are uniquely required for growth on $C_{1}$ compounds are inducible by the $C_{1}$ compounds on which the bacteria are grown (Large \& Quayle, 1963; Dunstan, Anthony \& Drabble, 1972; Large \& Carter, 1973). In the facultative methanol-utilizing bacterium Pseudomonas AMI, some $\mathrm{C}_{\mathbf{1}^{-}}$ specific enzymes are repressed by succinate and some are not (Dunstan et al., 1972; Large \& Quayle, 1963). These enzymes appear to be coordinately controlled, and Dunstan et al. (1972) have suggested that they are under operonic control in Pseudomonas AMr.

The isolation and characterization of Methylobacterium organophilum (Patt et al., I974; Patt, Cole \& Hanson, 1976) has permitted the study of enzyme regulation in a methaneutilizing bacterium for the first time. Previous studies have shown that the ability of $M$. organophilum to oxidize methane and the synthesis of intracytoplasmic membranes occurred only in organisms grown on methane (Patt et al., 1974). Such studies are important in defining markers for biochemical and genetic analyses of $C_{1}$ metabolism, methane oxidation and membrane synthesis. This paper describes the response of several enzyme activities in $\boldsymbol{M}$. organophilum to changes in the substrates used for growth.

\section{METHODS}

Organism. Methylobacterium organophilum (ATCC27886; Patt et al., 1976) was used in all experiments.

Media and growth conditions. The modified nitrate mineral salts medium (NMS) previously described (Patt et al., 1976) was used for all studies. Succinate was dissolved in distilled water, sterilized separately and added directly to the growth medium at $0.1 \%(\mathrm{w} / \mathrm{v})$. Methanol $(96 \%, \mathrm{v} / \mathrm{v})$ was filter-sterilized and added separately to the growth medium at $0.5 \%(\mathrm{v} / \mathrm{v})$. All cultures were incubated at $30{ }^{\circ} \mathrm{C}$. Liquid cultures were incubated on rotary shakers.

Preparation of extracts. Extracts used for enzyme assays were prepared as described previously (O'Connor \& Hanson, 1975). Protein was estimated by the method of Lowry et al. (1951). 
Enzyme assays. Hydroxypyruvate reductase [D-glycerate: $\mathrm{NAD}^{+}$oxidoreductase, EC I.I I. 29], formatetetrahydrofolate ligase [formate: tetrahydrofolate ligase (ADP-forming), EC 6.3.4.3] and methylenetetrahydrofolate dehydrogenase [5,10-methylenetetrahydrofolate: NADP ${ }^{+}$oxidoreductase, EC 1.5.I.5] were assayed by the methods of Large \& Quayle (1963). Other assays were: serine-glyoxylate aminotransferase [L-serine: glyoxylate aminotransferase, EC 2.6.1.45], Blackmore \& Quayle (1970); glycerate kinase [ATP: D-glycerate 3-phosphotransferase, EC 2.7.1.31], Heptinstall \& Quayle (1970); phosphoenolpyruvate carboxylase [orthophosphate:oxaloacetate carboxy-lyase (phosphorylating), EC 4.I.I.3I], Canovas \& Kornberg (1969); serine transhydroxymethylase [5,10-methylenetetrahydrofolate:glycine hydroxymethyltransferase, EC 2. I .2 . I ], O'Connor \& Hanson (1975); $N^{5}$-formyltetrahydrofolate cyclodehydrase, Greenberg (197I); malate synthase [L-malate glyoxylate-lyase (CoA-acetylating), EC 4. I . 3 . 2], Dixon \& Kornberg (1959); citrate synthase [citrate oxaloacetate-lyase (pro-3S- $\mathrm{CH}_{2} \cdot \mathrm{COO}^{-} \rightarrow$ acetyl-CoA), EC 4. I .3.7], Srere, Brazil \& Gonen (1963); and 2-oxoglutarate dehydrogenase [2-oxoglutarate: lipoate oxidoreductase (decarboxylating and acceptor-succinylating), EC I .2.4.2], Tanaka \& Hanson (1975).

Methanol dehydrogenase and formaldehyde dehydrogenase were assayed by measuring the methanolor formaldehyde-dependent oxygen uptake in the presence of phenazine methosulphate (PMS). Oxygen uptake was measured by adding $0.8 \mathrm{ml}$ buffer (0.015 M-Tris/0.02 $\mathrm{M}-\mathrm{NH}_{4} \mathrm{Cl}, \mathrm{pH} 9.0$ ) and $0.1 \mathrm{ml}$ PMS (I mg $\mathrm{ml}^{-1}$ ) to the chamber of a Rank oxygen electrode (Rank Bros., Bottisham, Cambridgeshire). Extract and buffer were added to bring the volume to $0.95 \mathrm{ml}$. Methanol or formaldehyde $[0.05 \mathrm{ml}$ of a $1 \%(\mathrm{v} / \mathrm{v})$ solution] was added after methanol-independent oxygen consumption had stopped.

Mutant isolation. Mutants unable to grow on $C_{1}$ compounds were isolated using the ultraviolet light procedure described previously (O’Connor, Wopat \& Hanson, 1977).

Reversion tests. A heavy suspension of each methanol- mutant (i.e. unable to grow on methanol) was spread on to a plate of NMS plus methanol plus $0.03 \%$ (w/v) Casamino acids. A filter soaked in $N$-methyl$N^{\prime}$-nitro- $N$-nitrosoguanidine (NTG, $2 \mathrm{mg} \mathrm{ml}^{-1}$ ) or ethyl methanesulphonate (EMS, I: Io dilution) was placed in the centre of each plate.

\section{RESULTS}

\section{Enzyme activities}

Of the enzymes in bacteria grown on methanol, succinate or methanol plus succinate, those specific for $\mathrm{C}_{1}$ assimilation (hydroxypyruvate reductase, serine-glyoxylate aminotransferase, glycerate kinase and glyoxylate-activated serine transhydroxymethylase) (Quayle, 1972; O'Connor \& Hanson, 1975) showed high activities in methanol-grown bacteria, low activities in succinate-grown bacteria and intermediate activities (30 to $50 \%$ lower) in bacteria grown on methanol plus succinate (Table I). Of the enzymes involved in, but not specific for, $C_{1}$ assimilation (Quayle, I972), phosphoenolpyruvate carboxylase and methylenetetrahydrofolate dehydrogenase activities showed a trend similar to the $C_{1^{-}}$ specific enzymes, while formate-tetrahydrofolate ligase and $N^{5}$-formyltetrahydrofolate cyclodehydrase were not repressed by succinate and were present in methanol-grown bacteria. 2-Oxoglutarate dehydrogenase, citrate synthase and malate synthase activities were highest in succinate-grown organisms and lower with the other two growth conditions. Methanol dehydrogenase and formaldehyde dehydrogenase are involved in both carbon assimilation and energy production (Quayle, I972). These enzymes had similar activities in organisms grown on methanol or methanol plus succinate, but only low activities in succinate-grown organisms. Table 2 gives values from the literature for the specific activities of these enzymes in some facultative methanol-utilizing bacteria.

\section{Induction and dilution curves}

When succinate-grown bacteria were washed and resuspended in medium containing methanol, four enzymes specific for $\mathrm{C}_{1}$ assimilation were fully induced before noticeable growth occurred (Fig. I $a$ ). With methanol-grown bacteria exposed to succinate, the reverse situation occurred (Fig. I $b$ ). Formaldehyde dehydrogenase was not included in this particular study, since the observed activity may be due to two separate enzymes, one of which is the methanol dehydrogenase (Patel, Mandy \& Hoare, 1973; H. Wolf, unpublished data). 
Table 1. Enzyme activities in extracts of $M$. organophilum grown on methanol, methanol plus succinate or succinate

Enzyme activities are expressed as $\mu \mathrm{mol}$ product $\mathrm{min}^{-1}$ (mg protein) ${ }^{-1}$, except where indicated.

Enzyme

Hydroxypyruvate reductase

Serine-glyoxylate aminotransferase

Serine transhydroxymethylase (glyoxylate-activated)

Methanol dehydrogenase

Formaldehyde dehydrogenase

Glycerate kinase

Phosphoenolpyruvate carboxylase

Formate-tetrahydrofolate ligase

$N^{5}$-Formyltetrahydrofolate cyclodehydrase

Methylenetetrahydrofolate dehydrogenase

Malate synthase

Citrate synthase

2-Oxoglutarate dehydrogenase
Growth substrate

$\begin{array}{lcl}\text { Methanol } & \begin{array}{c}\text { Methanol } \\ + \\ \text { succinate }\end{array} & \text { Succinate } \\ 0.58 & 0.38 & 0.14 \\ 0.17 & 0.11 & 0.01 \\ 0.10 & 0.06 & 0.005 \\ 0.09 & 0.08 & 0.03 \\ 0.11 & 0.11 & 0.02 \\ 0.15 & 0.07 & \text { ND } \\ 0.03 & 0.01 & 0.003 \\ 0.12^{*} & 0.03^{*} & 0.03^{*} \\ 4.7^{*} & 4.4^{*} & 4.9^{*} \\ 0.29 & 0.27 & 0.05 \\ 0.007 & 0.006 & 0.016 \\ 0.02 & 0.03 & 0.10 \\ 0.001 & 0.013 & 0.086\end{array}$

ND, Not detectable.

* Expressed as nmol product $\min ^{-1}$ (mg protein) $)^{-1}$.

Table 2. Published values of enzyme activities in Pseudomonas AMI and Pseudomonas 3A2

Enzyme activities are expressed as $\mu$ mol product $\min ^{-1}$ (mg protein $)^{-1}$, except where indicated.

Growth substrate

Enzyme

\section{Pseudomonas AMI}

Hydroxypyruvate reductase

Serine-glyoxylate aminotransferase

Serine transhydroxymethylase (total activity)

Methanol dehydrogenase

Formaldehyde dehydrogenase (dye-linked)

Glycerate kinase

Phosphoenolpyruvate carboxylase

Formate-tetrahydrofolate ligase

Methylenetetrahydrofolate dehydrogenase

Malate synthase

Citrate synthase

Pseudomonas 3A2

2-Oxoglutarate dehydrogenase

$\overbrace{\text { Methanol }}^{\begin{array}{c}\text { Methanol } \\ + \\ \text { succinate }\end{array} \text { Succinate }}$ Ref. $\dagger$

$\begin{array}{lcll}\mathrm{I} \cdot 57 & 0.32 & 0.35 & \mathrm{I}, 2 \\ 0.083 & 0.008 & 0 & 2 \\ 0.042 & - & 0.014 & \mathrm{I} \\ 0.54 & 0.49 & 0.06 & 2 \\ 0.003 & - & - & 3 \\ 0.05 & 0.03 & 0.016 & 2 \\ 0.13 & 0.087 & 0 & 4 \\ 10^{*} & - & 1 \cdot 2^{*} & 1 \\ 0.4 & - & 0.22 & \mathrm{I} \\ 0.08 & - & 0.07 & 4 \\ 0.067 & - & 0.12 & \mathrm{I} \\ 0.002 & - & & \\ & - & - & 5\end{array}$

* Expressed as nmol product $\min ^{-1}$ (mg protein) ${ }^{-1}$.

† I, Large \& Quayle (1963); 2, Dunstan et al. (1972); 3, Johnson \& Quayle (1964); 4, Salem et al. (1973);

5 , Colby \& Zatman (1972). 

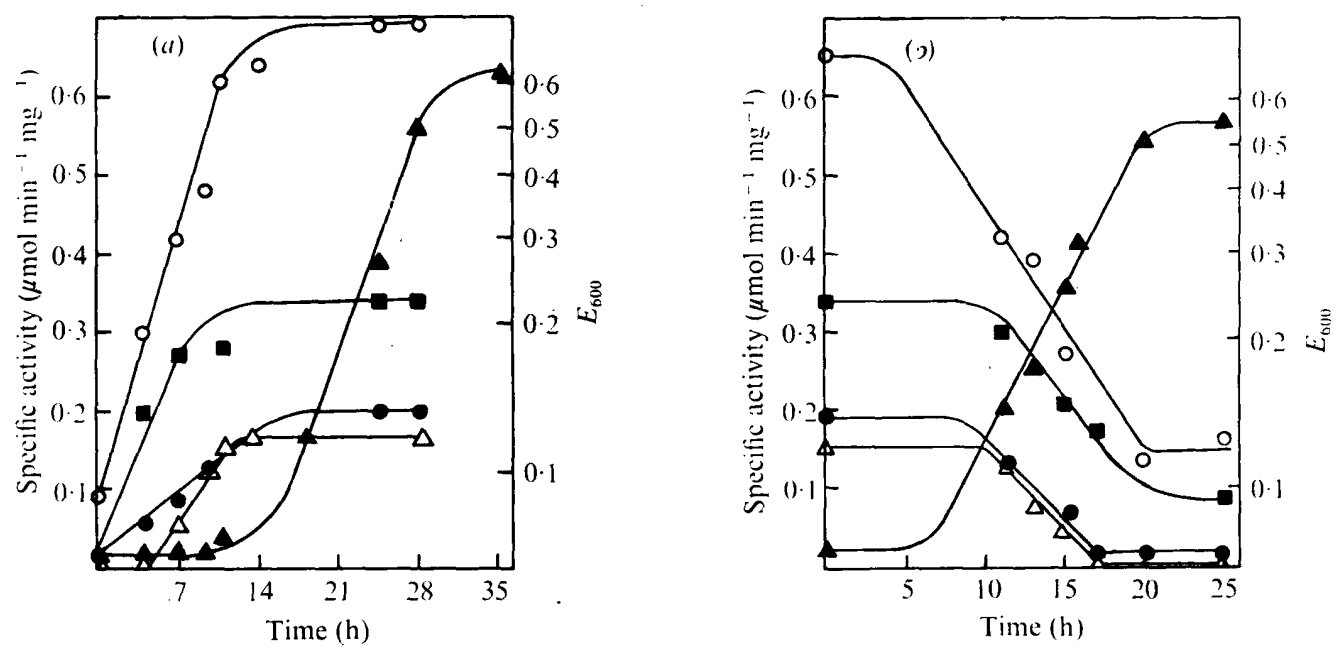

Fig. I. (a) Induction and $(b)$ repression of four enzymes specific for $\mathrm{C}_{1}$ metabolism. (a) Succinategrown bacteria were washed and resuspended in medium containing methanol at time zero; $(b)$ methanol-grown bacteria were washed and resuspended in medium containing succinate at time zero. $\bigcirc$, Hydroxypyruvate reductase; 0 , serine-glyoxylate aminotransferase; $\mathbf{\square}$, methanol dehydrogenase; $\triangle$, glycerate kinase; $\Delta$, bacterial growth measured as extinction at $600 \mathrm{~nm}$.

Similar results for the glyoxylate-activated serine transhydroxymethylase were published previously (O’Connor \& Hanson, I975).

\section{Mutants}

Several mutants were isolated which grew on succinate but showed little or no growth when $C_{1}$ compounds were used as sole carbon and energy sources. Table 3 shows enzyme activities for these mutants. Strain $17 \mathrm{M}$ is deficient in methanol dehydrogenase and strain $8 \mathrm{Z}$ is deficient in glycerate kinase. Strains $8 \mathrm{~A}, 4 \mathrm{M}, 7 \mathrm{~A}, \mathrm{IM}, 2 \mathrm{M}, 3 \mathrm{M}$ and $\mathrm{I7} \mathrm{A}$ all lack methanol dehydrogenase activity and show little or no activity of two or more of the other enzymes specific for growth on $\mathrm{C}_{1}$ compounds. Strains 7A, I7A, I7M, IM, 2M and 3M were not revertible by NTG or EMS.

\section{DISCUSSION}

The regulation of the synthesis of enzymes uniquely utilized for growth on $\mathrm{C}_{1}$ compounds in the facultative methylotroph $M$. organophilum differed in some ways from that of the methanol-utilizing bacterium Pseudomonas AMI. In both bacteria, enzymes involved in growth on $\mathrm{C}_{1}$ compounds were induced by methanol, and methanol dehydrogenase was not repressed by growth in medium containing methanol plus succinate (Dunstan et al., 1972). However, three of the key assimilatory enzymes (hydroxypyruvate reductase, serineglyoxylate aminotransferase and glycerate kinase) were strongly repressed by growth on methanol plus succinate in Pseudomonas AMr (Dunstan et al., 1972).

None of the enzymes specific for growth on $C_{1}$ compounds tested was strongly repressed by growth on methanol plus succinate in $M$. organophilum, although both substrates are utilized (O'Connor \& Hanson, I975). In addition, five enzymes specific for $C_{1}$ metabolism (hydroxypyruvate reductase, methanol dehydrogenase, serine-glyoxylate aminotransferase, glycerate kinase and the glyoxylate-activated serine transhydroxymethylase) were induced when bacteria were changed from succinate medium to methanol medium, and were diluted out when bacteria were changed from methanol medium to succinate medium (Fig. I, and 
Table 3. Enzyme activities in methanol- mutants and wild-type M. organophilum

All strains were grown on media containing $0.1 \%$ succinate plus $0.5 \%$ methanol. Activities are expressed as $\mu \mathrm{mol} \mathrm{min}^{-1}$ (mg protein) ${ }^{-1}$.

\begin{tabular}{|c|c|c|c|c|c|c|}
\hline \multirow[b]{2}{*}{ Strain } & \multirow{2}{*}{$\begin{array}{l}\text { Hydroxy- } \\
\text { pyruvate } \\
\text { reductase }\end{array}$} & \multirow{2}{*}{$\begin{array}{l}\text { Serine- } \\
\text { glyoxylate } \\
\text { amino- } \\
\text { transferase }\end{array}$} & \multirow{2}{*}{$\begin{array}{c}\text { Methanol } \\
\text { dehydro- } \\
\text { genase }\end{array}$} & \multirow[b]{2}{*}{$\begin{array}{c}\text { Glycerate } \\
\text { kinase }\end{array}$} & \multicolumn{2}{|c|}{$\begin{array}{c}\text { Serine } \\
\text { transhydroxymethylase }\end{array}$} \\
\hline & & & & & +Glyoxylate & - Glyoxylate \\
\hline Wild type & 0.38 & $0 . I I$ & 0.08 & 0.07 & $0 \cdot 16$ & 0.13 \\
\hline $17 \mathrm{M}$ & 0.28 & 0.08 & ND & 0.06 & 0.19 & 0.16 \\
\hline $8 z$ & 0.27 & 0.08 & 0.09 & 0.006 & 0.12 & 0.07 \\
\hline $8 A$ & 0.05 & 0.03 & ND & 0.06 & 0.20 & 0.01 \\
\hline $4 M$ & 0.03 & 0.01 & ND & 0.01 & 0.08 & 0.10 \\
\hline $7 \mathrm{~A}$ & ND & ND & ND & 0.10 & 0.016 & 0.011 \\
\hline I7A & 0.03 & 0.001 & ND & 0.03 & 0.03 & 0.03 \\
\hline IM & 0.06 & 0.02 & ND & ND & 0.004 & 0.019 \\
\hline $2 M$ & 0.15 & 0.05 & ND & ND & 0.019 & 0.024 \\
\hline $3 M$ & 0.10 & 0.04 & ND & ND & 0.011 & 0.017 \\
\hline
\end{tabular}

ND, Not detectable.

O'Connor \& Hanson, 1975). The results suggest that these enzymes are inducible, but not repressed when succinate is added as an additional carbon and energy source.

Two Krebs cycle enzymes were repressed in methanol-grown bacteria, indicating that the Krebs cycle is not as important in $M$. organophilum during growth on methanol as it is during growth on succinate.

Coordinate control of the above five $\mathrm{C}_{1}$-specific enzymes involving a common inducer is suggested by the data presented. The methanol dehydrogenase may be under separate control, since it is not repressed by succinate and the other enzymes are moderately repressed.

Possibly some or all of the genes coding for the five $\mathrm{C}_{1}$-specific enzymes belong to a single regulon. The enzyme activities in the methanol- mutants tested suggest this possibility. Seven separate isolates are pleiotropically negative. Five of these are not revertible by NTG or EMS, and might contain frameshift mutations. The other two, which are revertible by NTG and EMS, might contain nonsense mutations or mutations in a regulatory gene or a gene coding for an inducer. The question of operonic control can only be answered by genetic mapping, a tool which is now available in this organism (O'Connor et al., I977).

We are grateful to Christine Schilling and Mary Zelinski for their assistance in this work. M. L. O'Connor was supported by a predoctoral fellowship from the American Association of University Women. This research was also supported by the College of Agricultural and Life Sciences, University of Wisconsin, Madison, and a grant from the National Science Foundation (BMS 75-I40I2).

\section{REFERENCES}

Blackmore, M. A. \& Quayle, J. R. (1970). Microbial growth on oxalate by a route not involving glyoxylate carboligase. Biochemical Journal 118, 53-59.

Canovas, J. L. \& Kornberg, H. L. (I969). Phosphoenolpyruvate carboxylase from Escherichia coli. Methods in Enzymology 13, 288-292.

Colby, J. \& ZATMaN, L. J. (1972). Hexose phosphate synthase and tricarboxylic acid cycle enzymes in bacterium $4 \mathrm{~B} 6$, an obligate methylotroph. Biochemical Journal 128, 1374-1 376.
Dixon, G. H. \& KornberG, H. L. (1959). Assay methods for key enzymes of the glyoxylate cycle. Biochemical Journal 72, 3P.

Dunstan, P. M., Anthony, C. \& Drabble, W. T. (1972). Microbial metabolism of $C_{1}$ and $C_{2}$ compounds. The role of glyoxylate, glycollate and acetate in the growth of Pseudomonas AMI on ethanol and on $\mathbf{C}_{1}$ compounds. Biochemical Journal 128, 107-1 I5.

GREENBERG, D. M. (1971). $N^{5}$-Formyltetrahydrofolate acid cyclodehydrase. Methods in Enzymology r8B, 786-789. 
HePtinstall, J. \& Quayle, J. R. (1970). Pathway leading to and from serine during growth of Pseudomonas AMI on $\mathrm{C}_{1}$ compounds or succinate. Biochemical Journal 117, 563-572.

Johnson, P. A. \& Quayle, J. R. (1964). Microbial growth on $\mathrm{C}_{1}$ compounds. 6. Oxidation of methanol, formaldehyde and formate by methanolgrown Pseudomonas AMI. Biochemical Journal 93, 28I -290 .

Large, P. J. \& Carter, R. H. (1973). Specific activities of enzymes of the serine pathway of carbon assimilation in Pseudomonas aminovorans and Pseudomonas MS grown on methylamine. Biochemical Society Transactions I, 129 I-I 293.

LARGE, P. J. \& QUAYLE, J. R. (1963). Microbial growth on $\mathrm{C}_{1}$ compounds. 5. Enzyme activities in extracts of Pseudomonas AMI. Biochemical Journal 87, 386-395.

Lowry, O. H., Rosebrough, N. J., Farr, A. L. \& Randall, R. J. (I95I). Protein measurement with the Folin phenol reagent. Journal of Biological Chemistry r93, 265-275.

O'Connor, M. L. \& Hanson, R. S. (1975). Serine transhydroxymethylase isoenzymes from a facultative methylotroph. Journal of Bacteriology 124, 985-996.

O'Connor, M. L., Wopat, A. E. \& Hanson, R. S. (1977). Genetic transformation of Methylobacterium organophilum. Journal of General Microbiology 98, 265-272.
Patel, R. N., Mandy, W. J. \& Hoare, D. S. (1973). Physiological studies of methane- and methanoloxidizing bacteria: immunological comparison of a primary alcohol dehydrogenase from Methylococcus capsulatus and Pseudomonas sp. M27. Journal of Bacteriology Ir3, 937-945.

Patt, T. E., Cole, G. C., Bland, J. \& Hanson, R. S. (1974). Isolation and characterization of bacteria that grow on methane and organic compounds as sole sources of carbon and energy. Journal of Bacteriology 120, 955-964.

PatT, T. E., Cole, G. C. \& Hanson, R. S. (1976). Methylobacterium, a new genus of facultatively methylotrophic bacteria. International Journal of Systematic Bacteriology 26, 226-229.

QUAYLE, J. R. (1972). The metabolism of one-carbon compounds by micro-organisms. Advances in Microbial Physiology 7, 119-203.

Salem, A. R., Wagner, C., Hacking, A. J. \& QUAYLE, J. R. (I973). The metabolism of lactate and pyruvate by Pseudomonas AMI. Journal of General Microbiology 76, 375-388.

Srere, P. A., Brazil, H. \& Gonen, L. (I963). The citrate-condensing enzyme of pigeon breast muscle and moth flight muscle. Acta chemica scandinavica 17, 129-134.

TANAKA, N. \& Hanson, R. S. (1975). Regulation of the tricarboxylic acid cycle in Gram-positive, facultatively anaerobic bacilli. Journal of Bacteriology 122, 2 I 5-223. 